\title{
Research frontiers in community forest management
}

DOI:

10.1016/j.cosust.2018.06.003

\section{Document Version}

Accepted author manuscript

Link to publication record in Manchester Research Explorer

\section{Citation for published version (APA):}

Hajjar, R., \& Oldekop, J. A. (2018). Research frontiers in community forest management. Current Opinion in Environmental Sustainability, 32, 119-125. https://doi.org/10.1016/j.cosust.2018.06.003

\section{Published in:}

Current Opinion in Environmental Sustainability

\section{Citing this paper}

Please note that where the full-text provided on Manchester Research Explorer is the Author Accepted Manuscript or Proof version this may differ from the final Published version. If citing, it is advised that you check and use the publisher's definitive version.

\section{General rights}

Copyright and moral rights for the publications made accessible in the Research Explorer are retained by the authors and/or other copyright owners and it is a condition of accessing publications that users recognise and abide by the legal requirements associated with these rights.

\section{Takedown policy}

If you believe that this document breaches copyright please refer to the University of Manchester's Takedown Procedures [http://man.ac.uk/04Y6Bo] or contact uml.scholarlycommunications@manchester.ac.uk providing relevant details, so we can investigate your claim.

\section{OPEN ACCESS}




\title{
Research frontiers in community forest management
}

$$
\text { Reem Hajjar }{ }^{1,2^{*}} \text {, Johan A Oldekop }{ }^{2,3}
$$

$5 \quad{ }^{1}$ Department of Forest Ecosystems and Society, Oregon State University, OR 97331, USA

${ }^{2}$ Forest and Livelihoods: Assessment Research and Engagement (FLARE) network, School of Environment and Sustainability, University of Michigan, MI 48109, USA

${ }^{3}$ Department of Geography, The University of Sheffield, S10 2TN, UK

*Corresponding author: reem.hajjar@oregonstate.edu

\begin{abstract}
Community forest management (CFM) has been promoted worldwide as a means to conserve forests, recognize community rights, and improve local livelihoods. Here, we synthesize findings across recent CFM studies and identify two thematic and one methodological trend at the 15 forefront of CFM scholarship. The first thematic trend is an examination of community forest enterprises as hybrid business models. The second is the increase of studies examining how REDD+ can contribute to the goals of CFM, and vice versa. The key methodological trend is the use of secondary data sets to determine outcomes of CFM policies at regional and national scales. These three trends add new perspectives to the debate on the effectiveness of CFM as a forest policy and institutional intervention.
\end{abstract}




\section{Introduction}

Forests provide essential environmental services and contribute directly to the livelihoods of

25 more than one billion people living in or close to forests [1]. Since the mid-1980's, numerous governments and international organizations have promoted community forest management (CFM) as a way to consolidate and streamline various conservation, natural resource management rights, and rural development agendas [2]. While most forests are still under government ownership and control, local communities now manage approximately $13 \%$ of

30 forests globally. The proportion increases to $30 \%$ in low and middle income countries ${ }^{1}$, and international sustainability agendas have re-emphasized the importance of rights-based approaches to sustainable development ${ }^{2}[3]$.

The growth and expansion of community forest management globally has been accompanied by a comprehensive body of literature focusing on the conditions that promote and

35 facilitate equitable community forest management, and positive forest and livelihood outcomes. Much of this literature has focused on case study analyses to develop theoretical arguments and gather empirical evidence about how local institutional conditions and different governance arrangements influence community forest outcomes. These studies provide a complex picture of what drives social and environmental outcomes of CFM, with clear examples of successes and

40 failures. Several syntheses and meta-analyses have sought to bring together lessons learned from case studies around the world in an attempt to produce more generalizable findings about what conditions lead to favorable, or unfavorable, CFM outcomes [4-14]. Several of these studies point to the importance of tenure security, government support for CFM, and effective and appropriate regulatory frameworks $[4,7,10,11]$ as exogenous factors that aid in CFM success.

45 These add to the governance and institutional factors within communities that shape successful common-pool resource management, such as local rule-making autonomy [15], monitoring and sanctioning [16], local organization, social capital, and leadership [4,6,17,18].

This rich and growing literature on CFM continues to shed additional light on processes and outcomes, with scholars looking to answer the questions, what works where, and why? Here,

\footnotetext{
${ }^{1}$ RRI Tenure Data and Tools; URL: http://rightsandresources.org/en/work-impact/tenure-datatool/

${ }^{2}$ For example, see activities of the newly established International Land and Forest Tenure Facility http://thetenurefacility.org/
} 
50 we take stock of the CFM literature since $2014^{3}$, the year that data were collected for the latest systematic review [12]. We find that much of the literature continues to focus on case studies addressing themes that have dominated the literature since the 1990s, including (i) outcomes of CFM interventions, including whether CFM has increased local incomes, access to forest products, and forest cover - with mixed results; and (ii) power relations and institutional

55 arrangements when CFM processes have resulted in limited devolution of power and/or benefits. However, we also find three prominent trends, which we suggest are at the frontier of CFM scholarship. Two of these trends are thematic, and one is methodological. The first thematic trend examines the mechanics of community forest enterprises as hybrid business models that can drive local prosperity. The second trend focuses on how Reducing Emissions from

60 Deforestation and Forest Degradation (REDD+) mechanisms are superimposed on, and overlap with, existing decentralized institutional arrangements, and how they contribute to or impede community forest management goals. The final methodological trend focuses on the use of secondary socio-economic and environmental datasets to determine outcomes of CFM policies at regional and national scales, shifting scholarship away from local case studies. These research

65 frontiers provide new perspectives and methods with which to understand social and environmental synergies and tradeoffs of CFM.

\section{The mechanics of community forest enterprises}

The contributions of community forestry to local livelihoods has been a common theme in much

70 of the CFM literature to date, extensively describing CFM contributions to both subsistence and commercial livelihoods. However, less common are analyses of community forest enterprises (CFEs) as business models; social or hybrid enterprises aiming to balance community development and ecological sustainability, while remaining financially viable [19]. A series of

\footnotetext{
${ }^{3}$ From an initial pool of 749 articles obtained using search criteria related to CFM, we narrowed down our review to 82 articles by screening paper titles and abstracts for relevancy to CFM. We defined CFM as a forest being collectively managed by at least three households, and focus on natural forest management and reforestation projects in less industrialized nations in Latin American, African, and Asia-Pacific regions (where most community forests are located). We excluded cases of afforestation or exotic species plantations [11]. 40 of the 82 articles were categorized as addressing one of the three trends described here. In addition to the papers reviewed since 2014, we occasionally refer to key papers published before 2014 for comparisons with the most recent literature.
} 
recent papers have focused on community forest enterprises as businesses, primarily addressing 75 two topic areas: cost-benefit analyses that examine the financial efficiency and viability of CFEs; and exploring CFE's organizational behavior, from a business management perspective.

Past studies have noted the difficulties CFEs have in remaining financially viable without external support and funding, usually in the form of limited-term NGO or governmental aid $[17,20,21]$. More recent studies have demonstrated that financial viability of CFEs is possible,

80 but that it is dependent on key enabling conditions. In a sample of 30 CFEs in Mexico, all but one CFE showed profits in forest and timber management, and communities with lumber processing infrastructure saw the greatest returns despite high production costs relative to other countries [22]. Another study in Mexico examined the cost-effectiveness of various logging mechanisms and technologies, commenting on the need to balance efficiency and desired cobenefits such as employment [23], reflecting the multiple goals of these hybrid businesses. In the Brazilian Amazon, community timber production cooperatives were found to be financially viable in one region [43, Humphries et al. unpublished], but other community timber businesses in a similar region were less viable [25], with poor market access making it difficult to overcome the costs associated with managing a forest legally.

Recent works on CFEs have also focused on the internal workings of these hybrid business models, and how they interact with external contextual factors. In looking at CFEs as business entities, these works have borrowed theoretical frameworks from the business management literature on organizational behavior. Studies of managerial behavior in CFEs in Guatemala and Mexico found that different organizational forms play a role in reducing 95 transaction costs in market exchanges; the authors call for enabling environments that reduce information asymmetries in relations between CFEs and their exchange partners, through better commercial relationships, social innovation, and entrepreneurship [26,27]. Elsewhere, authors have documented how communities have evolved innovative internal governance institutions to reconcile differences and disagreements among community members, while also navigating 100 market turbulence [28]. Another study explored decision-making processes in verticallyintegrated CFEs, highlighting how different governance arrangements are used to manage tradeoffs between effectiveness and efficiency [29]. One study described different business models used by CFEs, with the authors stating that current typologies that characterize CFEs solely as social enterprises seem to be inadequate in capturing the variability in types of woodland 
105 enterprises [30]. Adding to the wide scholarship examining enabling environments conducive to fostering CFEs and other small-scale forest enterprises [31,32], recent work has also focused on internal CFE capacities, especially the need for competitive business and marketing skills, that are crucial for business success [33-35].

The above studies help to integrate perspectives of business management scholarship into

110 what has previously been dominated by development discourse and common-pool resources theory, and can help practitioners to think through CFM challenges in ways that can foster these unique business models.

\section{REDD+ and CFM}

115 While REDD+ is not a new topic, we find the focus on the links between CFM and REDD+ to be the most prominent trend in recent CFM literature, in terms of the number of articles addressing this topic. Although the primary objective of REDD+ is climate change mitigation, it has also received considerable attention for its potential "co-benefits", including socio-economic development through monetization of standing forests [36]. Within this strategy, there is growing 120 recognition that community forestry is a promising path for retaining and enhancing forest carbon stocks, while also delivering co-benefits such as improved livelihoods and biodiversity conservation [15,37-39]. Community-based carbon monitoring is also expected to be less costly than professional surveys, while also enhancing participation and transparency in the process, and increasing equity, efficiency, and effectiveness of REDD+ [19,22,23]. As such, many recent

125 studies have examined the possibilities of superimposing REDD + mechanisms on existing decentralized institutional arrangements [42], and what these mechanisms can contribute to the goals of CFM.

Many of these studies are future-focused, in that they (i) review the possible compatibility between CFM and hypothetical REDD+ institutional arrangements [43,44], (ii)

130 describe people's perceptions and expectations of anticipated REDD+ projects [45,46], or (iii) examine what is lacking in current arrangements that is needed for effective REDD+ implementation in the future [46-48]. Studies point to the following areas for improvement to enhance the probability that REDD+ and CFM institutions can work synergistically: resolving conflicting de jure and de facto community rights [49]; greater involvement of secondary-level 135 institutions that act as brokers between communities and other levels of governance [50]; 
incorporating local knowledges and practices in REDD+ planning [51]; and improving institutional coordination, equitable benefit sharing mechanisms, and community capacity for monitoring, reporting and verification [52]. A smaller number of studies examine impacts of existing carbon forestry and REDD+ projects on communities [53,54], with mixed outcomes.

140 Lastly, recent work has provided a critical and political ecology lens on REDD+, where authors have questioned the compatibility of a top-down REDD + mechanism and bottom-up adaptive management approach of CFM [55], criticized market-based conservation for enclosing the commons and causing conflict [56], and described REDD + as the next conservation "fad" that will do little to change actual forest management [57].

Although the future of REDD+ seems to be continually debated [40, 41], the links between REDD+ and CFM are a prominent focus of scholarship in the covered time period. Given that projects assessing REDD+ outcomes globally are starting to yield results ${ }^{4}$, and given continued international investments in REDD+ projects and plans [60], we expect to see more studies in the near-term evaluating the impact of REDD+ on communities and forests in CFM contexts as this mechanism takes further hold in forested regions in the Global South. The studies listed above begin to provide evidence, informed predictions, and critical analyses of how to reach more favorable outcomes in linking these two forest policies.

\section{Using secondary data and causal estimation methods to assess CFM outcomes}

155 Case study work has largely dominated the study of CFM management [12], and evidence syntheses have relied on the collation of case studies assessing the outcome of CFM using standardized methodologies that generate comparable data [15,61], or meta-analyses and systematic reviews $[4,5,7,8,10]$. These approaches have provided a wealth of information about the conditions under which CFM can lead to positive outcomes for forests and people, but have been critiqued for not providing representative assessments of a diversity of community forest management initiatives [12].

The past decade has seen a growing trend in the use of secondary data (e.g., remote sensing and representative household survey data) and development of advanced impact estimation techniques to conduct large-scale evaluations of conservation and development

\footnotetext{
${ }^{4}$ See, for example, CIFOR's Global Comparative Study (https://www.cifor.org/gcs/), and $[79,80]$
} 
165 interventions [62]. These approaches aim to provide more robust assessments and causal estimations of net outcomes by controlling for the non-random allocation of interventions and policies. Within the context of natural resource management, these approaches have been predominantly used to assess the effects of protected areas [63-65]. More recently, these approaches are being increasingly used to assess other kinds of interventions, including Payment 170 for Ecosystem Services schemes [66] and conservation concessions [67].

To date, only a handful of papers have used these techniques to assess outcomes of community forest management. In Peru, land titling of indigenous communities has been shown to reduce deforestation [68], and overall conservation outcomes on titled land appear to be better than those of protected areas, and similar to conservation concessions managed by non175 governmental entities [67]. In Madagascar, livelihood improvements of community forestry appear to be small [69] and positive forest outcomes only occur in community forests prohibiting commercial extraction [70]. Similarly, community-based initiatives in Tanzania have led to increased food security but not improved wealth or health outcomes [71]. So far, only one study that we are aware of has simultaneously assessed livelihood and forest outcomes of community 180 forest management, showing that community forest management has led to both livelihood improvements and reduced deforestation in Nepal, and that the outcomes co-occur without significant trade-offs (Oldekop et al. unpublished).

A major contribution of these studies has been to show the net impacts of community forest management on forests and livelihoods. Yet a key potential of these datasets and analyses 185 is the ability to (i) help us explain the relative effects of different interventions and how community forestry initiatives perform within broader policy mixes [67,72], and (ii) understand how social, economic, and biophysical factors shape different kinds of outcomes [62]. For example, poverty appears to be a limiting factor of forest outcomes in Nepal (Oldekop et al. unpublished), education and forest proximity moderate positive wealth outcomes in Madagascar

190 [69], and engagement of forest user groups with local government institutions is central to forest outcomes in Bolivia and Peru [73]. These studies, while limited in their ability to provide the contextual depth of individual case studies, add to the evidence base of CFM impacts and point broadly to drivers of positive social and environmental outcomes. 


\section{Conclusions}

The bulk of recent literature on CFM continues to address themes similar to those that have dominated the literature since the 1990s. While not new trends in CFM research, these studies

200 proffer additional localized evidence and understanding of local forest governance and institutions, with most studies pointing to valuable lessons for how CFM can be better supported in particular regions.

Beyond these themes, our review highlights three research frontiers that provide new perspectives and methods with which to understand community forest outcomes. Studies from all 205 three research frontiers continue to examine how community forests are used as potential pathways out of poverty and towards broader prosperity for forest-dependent people. Studies look at how the business perspective is increasing our understanding of the mechanisms used by CFEs to provide increased incomes in manners compatible with local needs and goals; how CFM can facilitate achievement of core REDD+ goals while also providing co-benefits including 210 poverty alleviation; and how secondary data sets can provide evidence at larger scales of CFM's provision of positive outcomes for people and forests. We expect that all three themes will become more prominent in the literature in coming years given recent policy and market trends, and as more data becomes available.

Community forest enterprises (CFEs) play important roles in improving livelihoods, food

215 security, and poverty reduction, while empowering local people [32,74]. Yet they continue to face a number of business-related challenges, such as poor market access, inadequate business and management skills, and unfavorable regulatory environments. Using the lens of welldeveloped business management scholarship can continue to aid our understanding of challenges and successes with these unique business models. Given the increasing demand for sustainable 220 and ethically sourced materials -and in particular as new wood technologies are increasingly being used in construction- this strand of research is likely to garner increased attention in the coming years as we better understand the potential contributions of CFEs in sustainable supply chains.

The majority of REDD+ initiatives are still at various stages of preparation and it is hence

225 difficult to generate a comprehensive narrative about lessons learned so far [75]. There is, however, a growing literature on the effectiveness of Payment for Environmental Services 
schemes [76,77] that can provide useful analogies to better understand potential REDD+ implementation. In addition, recent efforts to establish databases of active REDD + projects ${ }^{5}$ provide valuable information with which to generate new empirical evidence and syntheses.

230 Studying the interactions between REDD + and CFM, as a subset of overall REDD + projects, will likely gain prominence as more data becomes available.

Studies using large environmental and social datasets provide a novel way with which to understand the temporal and spatial dynamics of CFM. With that comes an opportunity to systematically study the factors that constrain and/or promote social and environmental synergies

235 and trade-offs over large geographical scales, and how CFM outcomes compare to outcomes of other conservation and development interventions. This understanding is critical for the targeting and development of better policies and interventions. A key constraint in the development of this strand of research is data. While remotely-sensed data [e.g. 70], and representative household surveys (e.g., Living Standards Measurement Survey and Demographic and Health Survey) and

240 national census data have become more widely available, gaining information about spatial boundaries and locations of community forests remains a challenge. The development of new, or expansion of existing, data repositories and platforms to share spatial data would greatly support the development of this emerging research theme.

\section{Acknowledgements}

We would link to thank Dan Miller, Pete Newton, Laura Vang Rasmussen and Cristy Watkins for helpful comments on previous versions of this manuscript, and three anonymous reviewers whose suggestions greatly improved the paper.

\section{References}

1. Newton P, Miller DC, Byenkya MAA, Agrawal A: Who are forest-dependent people? A taxonomy to aid livelihood and land use decision-making in forested regions. Land use policy 2016, 57:388-395.

2. Agrawal A, Chhatre A, Hardin R: Changing Governance of the World's Forests.

${ }^{5}$ For example, Simonet G, Agrawal A, Bénédet F, de Perthuis C, Haggard D, Jansen N, Karsenty A, Liang W, Newton P, Sales AM, et al.: International Database on REDD+ projects, linking Economic, Carbon and Communities data (version2). 2016. 
Science (80-) 2008, 320:1460-1462.

3. Nations U: Transforming our world: the 2030 agenda for sustainable development. 2015.

4. Pagdee A, Kim Y, Daugherty PJ: What Makes Community Forest Management Successful: A Meta-Study From Community Forests Throughout the World. Soc Nat Resour 2006, 19:33-52.

260 5. Oldekop JA, Bebbington AJ, Brockington D, Preziosi RF: Understanding the Lessons and Limitations of Conservation and Development. Conserv Biol 2010, 24:461-469.

6. Arts B, de Koning J: Community Forest Management: An Assessment and Explanation of its Performance Through QCA. World Dev 2017, 96:315-325.

7. Gilmour D: Forty years of community-based forestry - A review of its extent and 265 effectiveness. 2016.

8. Bowler DE, Buyung-Ali LM, Healey JR, Jones JPG, Knight TM, Pullin AS: Does community forest Management provide global environmental benefits and improve local welfare? Front Ecol Environ 2012, 10:29-36.

9. Sikor T, Baggio JA: Can Smallholders Engage in Tree Plantations? An Entitlements Analysis from Vietnam. World Dev 2014, 64:S101-S112.

10. Baynes J, Herbohn J, Smith C, Fisher R, Bray D: Key factors which influence the success of community forestry in developing countries. Glob Environ Chang 2015, 35:226-238.

11. Seymour F, La Vina T, Hite K: Evidence linking community-level tenure and forest condition: An annotated bibliography. 2014.

12. Hajjar R, Oldekop JA, Cronkleton P, Etue E, Newton P, Russel AJM, Tjajadi JS, Zhou W, Agrawal A: The data not collected on community forestry. Conserv Biol 2016, 30:1357-1362.

13. Hajjar R, Molnar A: Decentralized and community-based approaches. In Forests, Business and Sustainability. Edited by Panwar R, Kozak R, Hansen E. Routledge; 2016.

14. Fisher R: Lessons Learned From Community Forestry in Asia and their Relevance for REDD+. 2014.

15. Chhatre A, Agrawal A: Trade-offs and synergies between carbon storage and livelihood benefits from forest commons. Proc Natl Acad Sci 2009, 106:17667-17670. 
17. Hajjar R, McGrath DG, Kozak RA, Innes JL: Framing community forestry challenges with a broader lens: Case studies from the Brazilian Amazon. J Environ Manage 2011, 92:2159-2169.

18. Ostrom E: Reformulating the commons. Ambient Soc 2002, 6:1-22.

290 19. Antinori C, Bray DB: Community forest enterprises as entrepreneurial Firms: Economic and institutional perspectives from Mexico. World Dev 2005, 33:1529-1543.

20. Tomaselli MF, Hajjar R: Promoting community forestry enterprises in national REDD+ strategies: A business approach. Forests 2011, 2:283-300.

21. Medina G, Pokorny B: Avaliação financeira do manejo florestal comunitário. $N C N$ 295 Novos Cad NAEA 2011, 14:25-36.

22. Cubbage FW, Davis RR, Rodríguez Paredes D, Mollenhauer R, Kraus Elsin Y, Frey GE, González Hernández I a., Albarrán Hurtado H, Cruz AMS, Sala DNC: Community Forestry Enterprises in Mexico: Sustainability and Competitiveness. J Sustain For 2015, 9811:150615110954009.

300 23. Bray DB, Duran E, Hernández-Salas J, Luján-Alvarez C, Olivas-García M, GrijalvaMartínez I: Back to the future: The persistence of horse skidding in large scale industrial community forests in Chihuahua, Mexico. Forests 2016, 7:1-8.

24. Humphries S, Holmes TP, Kainer K, Koury CGG, Cruz E, de Miranda Rocha R: Are community-based forest enterprises in the tropics financially viable? Case studies from the Brazilian Amazon. Ecol Econ 2012, 77:62-73.

25. Piketty MG, Drigo I, Sablayrolles P, De Aquino EA, Pena D, Sist P: Annual cash income from community forest management in the Brazilian Amazon: Challenges for the future. Forests 2015, 6:4228-4244.

26. Carias Vega D, Keenan RJ: Agents or stewards in community forestry enterprises? Lessons from the Mayan Biosphere Reserve, Guatemala. Land use policy 2016, 52:255-265.

27. Carias Vega D, Keenan RJ: Transaction costs and the organization of CFEs: Experiences from ejidos in Quintana Roo, Mexico. For Policy Econ 2016, 70:1-8.

28. Bray DB: Muir and Pinchot in the Sierra Norte of Oaxaca: Governance of forest management and forest recovery in Pueblos Mancomunados. World Dev Perspect 2016, 4:8-10. 
29. Engbring G, Hall T, Hajjar R: Conflicts between core purposes: Decision-making and trade-offs in Oaxacan community forest enterprises. In Western Forestry Graduate Research Symposium. . 2017.

320 30. Ambrose-Oji B, Lawrence A, Stewart A: Community based forest enterprises in Britain: Two organising typologies. For Policy Econ 2015, 58:65-74.

31. Donovan J, Stoian D, Macqueen D, Grouwels S: The business side of sustainable forest management: Small and medium forest enterprise development for poverty reduction. Nat Resour Perspect 2006,

325 32. Macqueen D.: Forest Connect: reducing poverty and deforestation through support to community forest enterprises. Int For Rev 2008, 10:670-675.

33. Macqueen D: Enabling Conditions for Successful Community Forest Enterprises. Small-scale For 2013, 12:145-163.

34. Ellis EA, Kainer KA, Sierra-Huelsz JA, Negreros-Castillo P, Rodriguez-Ward D, DiGiano M: Endurance and adaptation of community forest management in Quintana Roo, Mexico. Forests 2015, 6:4295-4327.

35. Hajjar R, Badini OS, Kozak RA: Promoting small and medium forest enterprises in national REDD + strategies: A global analysis of enabling environments. Clim Policy 2016, 3062.

335 36. UN-REDD Programme: Operational Guidance : Engagement of Indigenous Peoples and Other Forest Dependent Communities. 2009,

37. Agrawal A, Angelsen A: Using community forest management to achieve REDD+ goals. In Realising REDD+: National strategy and policy options. Edited by Angelsen A. CIFOR; 2009.

340 38. Balooni K, Lund JF: Forest rights: The hard currency of REDD+. Conserv Lett 2014, 7:278-284.

39. Cronkleton P, Bray DB, Medina G: Community forest management and the emergence of multi-scale governance institutions: Lessons for REDD+ development from Mexico, Brazil and Bolivia. Forests 2011, 2:451-473.

345 40. Skutsch M, van Laake P: REDD as multi-level governance in the making. Energy Environ 2009, 19:831-844.

41. Agrawal A: The Role of Local Institutions in Adaptation to. Soc Dev 2008, 
doi:10.1596/978-0-8213-7887-8.

42. Walker W, Baccini A, Schwartzman S, Ríos S, Oliveira-Miranda MA, Augusto C, Ruiz MR, Arrasco CS, Ricardo B, Smith R, et al.: Forest carbon in Amazonia: The unrecognized contribution of indigenous territories and protected natural areas. Carbon Manag 2014, 5:479-485.

43. Khatun K, Gross-Camp N, Corbera E, Martin A, Ball S, Massao G: When Participatory Forest Management makes money: insights from Tanzania on governance, benefit sharing, and implications for REDD+. Environ Plan A 2015, 47:2097-2112.

44. Hodgdon BD, Hayward J, Samayoa O: Putting the plus first: community forest enterprise as the platform for REDD+ in the Maya Biosphere Reserve, Guatemala. Trop Conserv Sci 2013, 6:365-383.

45. Skutsch M, Borrego A, Morales-Barquero L, Paneque-Gálvez J, Salinas-Melgoza M, Ramírez MI, Pérez-Salicrup D, Benet D, Monroy S, Gao Y: Opportunities, constraints and perceptions of rural communities regarding their potential to contribute to forest landscape transitions under REDD + : case studies from Mexico. Int For Rev 2015, 17:65-84.

46. Bastakoti RR, Davidsen C: Optimism, hopes and fears : Local perceptions on REDD + in Nepalese community forests. Int For Rev 2017, XX:1-16.

47. Newton P, A Oldekop J, Brodnig G, Karna BK, Agrawal A: Carbon, biodiversity, and livelihoods in forest commons: synergies, trade-offs, and implications for REDD+. Environ Res Lett 2016, 11:044017.

48. Awung N, Marchant R: Investigating the Role of the Local Community as CoManagers of the Mount Cameroon National Park Conservation Project. Environments 2016, 3:36.

49. Loaiza T, Nehren U, Gerold G: REDD+ implementation in the Ecuadorian Amazon: Why land configuration and common-pool resources management matter. For Policy Econ 2016, 70:67-79.

375 50. Hajjar R, Kozak R: The evolution of forest producer associations and their current role in REDD+: Case studies from Quintana Roo, Mexico. Land use policy 2017, 60:373-383.

51. Van Vleet E, Bray DB, Durán E: Knowing but not knowing: Systematic conservation 
planning and community conservation in the Sierra Norte of Oaxaca, Mexico. Land use policy 2016, 59:504-515.

52. Newton P, Schaap B, Fournier M, Cornwall M, Rosenbach DW, DeBoer J, Whittemore J, Stock R, Yoders M, Brodnig G, et al.: Community forest management and REDD+. For Policy Econ 2015, 56:27-37.

53. Hendrickson CY, Corbera E: Participation dynamics and institutional change in the Scolel Té carbon forestry project, Chiapas, Mexico. Geoforum 2015, 59:63-72.

54. Khatun K, Corbera E, Ball S: Fire is REDD+: offsetting carbon through early burning activities in south-eastern Tanzania. Oryx 2016, 51:1-10.

55. Osborne T: Tradeoffs in carbon commodification: A political ecology of common property forest governance. Geoforum 2015, 67:64-77.

390 56. Scheba A, Rakotonarivo OS: Territorialising REDD+: Conflicts over market-based forest conservation in Lindi, Tanzania. Land use policy 2016, 57:625-637.

57. Lund JF, Sungusia E, Mabele MB, Scheba A: Promising Change, Delivering Continuity: REDD+ as Conservation Fad. World Dev 2017, 89:124-139.

58. Angelsen A, Brockhaus M, Duchelle AE, Larson A, Martius C, Sunderlin WD, Verchot L, Wong G, Wunder S: Learning from REDD+: a response to Fletcher et al. Conserv Biol 2017, 31:718-720.

59. Fletcher R, Dressler W, Büscher B, Anderson ZR: Questioning REDD+ and the future of market-based conservation. Conserv Biol 2016, 30:673-675.

60. Angelsen A: REDD+ as Result-based Aid: General Lessons and Bilateral Agreements of Norway. Rev Dev Econ 2017, 21:237-264.

61. Persha L, Agrawal A, Chhatre A: Social and Ecological Synergy: Local Rulemaking, Forest Livelihoods, and Biodiversity Conservation. Science 2011, 331:1606.

62. Ferraro $\mathrm{P}$, Hanauer $\mathrm{M}$ : Advances in measuring the environmental and social impacts of environmental programs. Annu Rev Environ Resour 2014, 39:495-517.

405 63. Andam KS, Ferraro PJ, Sims KRE, Healy A, Holland MB: Protected areas reduced poverty in Costa Rica and Thailand. Proc Natl Acad Sci 2010, 107:9996-10001.

64. Joppa L, Pfaff A: Global protected area impacts. Proc R Soc B 2011, 278:1633-1638.

65. Miranda JJ, Corral L, Blackman A, Asner G, Lima E: Effects of protected areas on forest cover and local communities. Evidence from the Peruvian Amazon. World Dev 
2016, 78:288-307.

66. Alix-Garcia JM, Sims KRE, Yañez-Pagans P: Only one tree from each seed? Environmental effictiveness and poverty alleviation in Mexico's Payment for Ecosystem Services program. Am Econ J Econ Policy 2015, 7:1-40.

67. Schleicher J, Peres CA, Amano T, Llactayo W, Leader-Williams N: Conservation performance of different conservation governance regimes in the Peruvian Amazon. Sci Rep 2017, 7:11318.

68. Blackman A, Corral L, Lima ES, Asner GP: Titling indigenous communities protects forests in the Peruvian Amazon. Proc Natl Acad Sci 2017, 114:4123-4128.

69. Rasolofoson RA, Ferraro PJ, Ruta G, Rasamoelina MS, Randriankolona PL, Larsen HO, Jones JPG: Impacts of community forest management on human economic well-being across Madagascar. Conserv Lett 2017, 10:346-353.

70. Rasolofoson RA, Ferraro PJ, Jenkins CN, Jones JPG: Effectiveness of community forest management at reducing deforestation in Madagascar. Biol Conserv 2015, 184:271277.

425 71. Pailler S, Naidoo R, Burgess ND, Freeman OE, Fisher B: Impacts of community-based natural resource management on wealth, food security and child health in Tanzania. PLoS One 2015, 10:e133252.

72. Sims K, Alix-Garcia JM: Parks versus PES: Evaluating direct and indirect incentivebased land conservation in Mexico. J Environ Econ Manage 2017, In press.

430 73. Wright GD, Andersson KP, Gibson CC, Evans TP: Decentralization can help reduce deforestation when user groups engage with local government. Proc Natl Acad Sci 2016, doi:10.1073/pnas.1610650114.

74. Mayers J: Poverty Reduction through Commercial Forestry What evidence ? What prospects ? For Dialoguelogue 2006,

435 75. Alix-Garcia J, Wolff H: Payment for Ecosystem Services from Forests. Annu Rev Resour Econ 2014, 6:361-380.

76. Börner J, Baylis K, Corbera E, Ezzinde-de-Blas D, Honey-Rosés J, Persson UM, Wunder S: The effectiveness of Payment for Ecosystem Services. World Dev 2017, 96:374-395.

77. Sills EO, de Sassi C, Jagger P, Lawlor K, Miteva DA, Pattanayak SK, Sunderlin WD: 
impacts of conservation interventions on local well-being. Glob Environ Chang 2017, 43:148-160.

78. Hansen, M. C., P. V. Potapov, R. Moore, M. Hancher, S. A. Turubanova, A. Tyukavina, D. Thau, S. V. Stehman, S. J. Goetz, T. R. Loveland, A. Kommareddy, A. Egorov LC, Justice CO, Townshend JRG: High-Resolution Global Maps of 21st-Century Forest Cover Change (15 November): 850-53. Science (80- ) 2013, 342:850-53.

79. Myers R, Larson AM, Ravikumar A, Kowler LF, Yang A, Trench T: Messiness of forest governance: How technical approaches suppress politics in REDD+ and conservation projects. Glob Environ Chang 2018, doi:10.1016/j.gloenvcha.2018.02.015.

450 80. Sunderlin WD, de Sassi C, Sills EO, Duchelle AE, Larson AM, Resosudarmo IAP, Awono A, Kweka DL, Huynh TB: Creating an appropriate tenure foundation for REDD+: The record to date and prospects for the future. World Dev 2018, 106:376392. 